medRxiv preprint doi: https://doi.org/10.1101/2020.11.26.20239327; this version posted November 30, 2020. The copyright holder for this preprint (which was not certified by peer review) is the author/funder, who has granted medRxiv a license to display the preprint in perpetuity. All rights reserved. No reuse allowed without permission.

\title{
Changing case fatality risk for COVID-19 over time in selected European countries
}

\author{
Heiko Becher ${ }^{1}$, Katharina Olszewski ${ }^{1}$, Sarah Wiegel ${ }^{1}$, Olaf Müller $^{2}$ \\ ${ }^{1}$ Institute of Medical Biometry and Epidemiology, University Medical Center Hamburg-Eppendorf, \\ Hamburg, Germany \\ ${ }^{2}$ Institute of Global Health, Medical School, Ruprecht-Karls-University, Heidelberg, Germany.
}

Corresponding author: Heiko Becher, h.becher@uke.de 


\title{
Key words
}

Covid-19, case fatality risk, Germany, Europe, case reporting,

\begin{abstract}
Objectives To illustrate the development of the case fatality risk (CFR) for COVID-19 over time using different assumptions for calculating the CFR.
\end{abstract}

Design Observational study.

Setting Selected European countries, 28 January to October 292020.

Participants Laboratory-confirmed COVID-19 cases and deaths due to COVID-19

Main outcome measure case fatality risk (CFR)

Results We show that the CFR has considerably decreased over time. This seems to be driven not only by increased testing but also by a reduced CFR among cases older than 60 years. Our data also confirm a significantly higher fatality risk for men than for women. The decline in the CFR is even more pronounced when only cases and deaths occurring in a specified time window are considered. This alternative estimation method has the advantage that early data where the bias due to the incomplete ascertainment of cases was arguably largest do not affect CFR estimates later on. We find similar results for other European countries.

Conclusion CFR estimates vary considerably depending on the underlying assumptions concerning their calculation. Reliable CFR estimates should not be based on cumulative numbers from the beginning of the pandemic but rather be based on more recent data only. 
medRxiv preprint doi: https://doi.org/10.1101/2020.11.26.20239327; this version posted November 30, 2020. The copyright holder for this

\section{Introduction}

The outbreak of coronavirus disease 2019 (COVID-19), which is caused by the severe acute respiratory syndrome corona virus 2 (SARS-CoV-2), has started in China by the end of 2019 $(1,2)$. It has rapidly developed into a serious pandemic, and by November 3 , a total of 46.871.264 cases were reported globally, with a total of 1.206 .187 deaths $(3,4)$. Until today, most cases and deaths occurred in the USA, India, Europe and Latin America, with a second wave of the epidemic now rapidly emerging in all countries of the northern hemisphere $(3,4)$.

A central parameter to assess the burden resulting from SARS-CoV-2/COVID-19 is the case fatality risk (CFR). Many publications report the crude CFR, calculated as the cumulative number of deaths divided by the cumulative number of cases. Yet, estimation of the crude CFR may be affected by several biases. More sophisticated methods are available but their application is often hampered by a lack of detailed data $(5,6)$.

In an earlier paper, we have shown that the different age distribution of cases in various European countries can explain a large proportion of observed differences in CFRs (7). Furthermore, dividing deaths by the number of cases at a certain point in time neglects the delay between infection and reported death. Thus, the denominator, i.e. the number of cases, should include a certain time lag so that only cases that allow for a sufficiently long follow-up time for a potential death to occur and be recorded are included in the analysis. According to the World Health Organization (WHO), time between symptom onset and death ranged from 2 to 8 weeks (8). Limited testing capacity, in particular at the beginning of the pandemic, made it difficult to estimate the denominator of the CFR. A number of studies reported varying numbers of asymptotic Covid-19 infections: the estimates range from $18 \%$ among the passengers of the cruise ship Diamond Princess (9) to $45 \%$ in a two-point prevalence survey in the Italian city of Vo (10). Asymptotic or mild cases are less likely to be reported to the surveillance system. Therefore, the CFR estimate will be higher among ascertained cases than among the entire population of cases. Finally, the overwhelmed health system in Italy in March 2020, for example, resulted in a very high CFR due to the limited capacity of intensive care facilities in hospitals (11). While there is sufficient knowledge that the CFR of SARSCoV-2/COVID-19 is strongly associated with old age and chronic diseases, there is less knowledge on other related factors $(5,2)$. 
The incomplete ascertainment of cases was particularly relevant during the early phase of the pandemic when testing capacity was low (2). If these underreported cases remain as cumulative numbers in later estimates, this bias somewhat decreases, but may still have a large impact on the CFR estimate. To avoid this bias, we present an alternative estimation method in this paper. We compare the crude and age- and sex-adjusted CFR estimates both using cumulative case and death numbers as well as cases and deaths occurring in a more recent time window. We also consider estimates by sex and age group.

In the light of our findings we discuss three further aspects which may have an effect on the CFR estimates: (a) the increase of the detection rate of the cases due to increasing testing capacities (12), (b) the improved treatment options for Covid-19 (13), and (c) mutations of the virus that may have led to changing lethality $(14,15)$.

\section{Data and Methods}

Data on daily age-and sex-specific case and fatality numbers in Germany until October 29 were obtained from the Robert-Koch-Institute (RKI) (16). The RKI disaggregated case and fatality numbers by sex and age, presented in six age groups $j=1, \ldots, 6$ as $0-4$ years, $5-14$ years, 15-34 years, 35-59 years, 60-79 years, and 80 years and above. International data on daily case and fatality numbers until October 29 were obtained from the European Centre for Disease Prevention and Control (17). These data are not separated by age group and sex. We restrict our analysis on European countries which accumulated more than 5000 deaths until October 28, 2020. These are Belgium, Germany, France, Italy, Netherlands, Romania, Russia, Spain, Sweden, Ukraine, UK.

We estimated the CFR for COVID-19 for the period April 1 until October 29 by using the following four methods:

(i) cumulative crude CFR (cumulative number of deaths up to "date" divided by cumulative number of cases up to "date minus k days")

$$
C F R_{\text {date,cumulative,crude }}=\frac{\sum_{i=\text { begin_date death } s_{i}}^{\text {date }}}{\sum_{i=\text { begin_date }-k}^{\text {date }-k} \text { cases }_{i}}
$$

(ii) cumulative age-standardized CFR (Germany only) (as (i), however age-standardized) 


$$
C F R_{\text {date,cumulative,age-standardized }}=\sum_{j=1}^{6} w_{j} \frac{\sum_{i=\text { begin_date deaths }}^{\text {date }}{ }_{i j}}{\sum_{i=\text { begin_date-k }}^{\text {date-k}} \text { cases }_{i j}}
$$

(iii) 60-day crude CFR (60-day crude CFR (number of deaths in the last 60 days before "date" divided by number of cases in days "date-60-k" until "date-k")

$$
C F R_{\text {date,60-day,crude }}=\frac{\sum_{i=\text { begin_date }}^{\text {date }}\left(\text { deaths }_{i}-\text { death }_{i-60}\right)}{\sum_{i=\text { begin_date }-k}^{\text {date-k}\left(\text { cases }_{i}-\text { cases }_{i-60}\right)}}
$$

(iv) 60-day age-standardized CFR (Germany only) (as (iii), however age-standardized)

$$
C F R_{\text {date }, 60-\text { day,age-standardized }}=\sum_{j=1}^{6} w_{j} \frac{\sum_{i=\text { begin_date }}^{\text {date }}\left(\text { death }_{i j}-\text { death }_{i-60, j}\right)}{\sum_{i=\text { begin_date-k }}^{\text {date-k }}\left(\operatorname{cases}_{i j}-\operatorname{cases}_{i-60, j}\right)}
$$

In addition, we calculated the CFR by age group and sex for Germany. The time delay between case reporting and death was initially assumed to be 7 days. A longer delay of 14 days was also considered for comparison. As "begin_date" we defined the first date of reporting a case which is January 28, 2020 for Germany. The weights $w_{j}$ for age standardization were chosen according to the standard European population 2013 (18). All calculations were performed using the statistical software package SAS.

Patient and Public Involvement

No patient involved

\section{Results}

$\rightarrow$ figure 1 here

Figure 1 shows the crude and age-standardized CFR for Germany from April to October 2020, both using cumulative numbers and considering only the last 60 days of any given date. All CFR estimates decrease over time, although their development over time varies considerably. After a peak during the first wave with a crude and age-standardized CFR of $8 \%$ and $7 \%$, respectively, the cumulative age-standardized CFR (red dashed line) rapidly decreases to about $3 \%$ and nearly plateaus thereafter. The cumulative crude CFR (blue dashed line) decreases slower but converges to a similar CFR estimate (around 4\%) at the end of the considered time period. The higher case-fatality risk among the older population drives the larger crude CFR estimate. Cumulating cases and death only over the last 60 days at each 
point of time results in a much sharper decrease of CFR estimates. The age-standardized CFR estimate at the end of the observation period using a 60-day window is $0.006(0.6 \%)$, about five-fold lower than the age-standardized estimate using the cumulative numbers. Since the age-standardized CFR decreases over time, the apparently low death numbers despite the rising number of cases over the last months cannot be attributed only to the changing agedistribution of the cases.

\section{$\rightarrow$ figure 2 here}

Figure 2 shows the age-standardized CFR estimates over time using a 60-day window, separately by sex. It confirms the observation from other studies that males have a higher death risk, with a factor of about two.

\section{$\rightarrow$ figure 3 here}

Figure 3 demonstrates the strong age-dependence of the CFR. The age-specific CFR estimates for the different age groups, 60-day window, are displayed. The age groups below 60 years (only the age group 35-59 is depicted here) have a constantly low CFR of 0,6\% and below. For the age group 60-79 years, the CFR continuously decreased from May to $1.35 \%$ on October 13. The CFR of the age group 80 years and above fluctuates around $12 \%$ in the months of July to October after a steep decline in the months before.

\section{$\rightarrow$ figures 4 and 5 here}

Figures 4 and 5 show the crude risks for selected European countries which have more than 5000 cumulative deaths until October. Estimates in figure 4 are based on cumulative numbers, estimates in figure 5 are based on a 60-day window. There is some decrease in the estimates for all countries except Russia using the cumulative numbers; however, the decrease is relatively small. The time window data, on the other hand, show a different picture. While for the Eastern European countries (Russia, Romania, Ukraine) the differences are relatively low, we observe in figure 4 a strong decrease in the other countries (Belgium, France, Germany, Italy, Netherlands, Spain, Sweden, UK) with crude estimates close to each other and all below $1 \%$. 
medRxiv preprint doi: https://doi.org/10.1101/2020.11.26.20239327; this version posted November 30, 2020. The copyright holder for this

$\rightarrow$ Table 1 here

Table 1_shows the estimates for the last date of our database, October 28, 2020. In this table, we also consider the effect on the CFR estimates when a longer period of 14 days from reporting a case to death is assumed instead of 7 days. In a period with daily rising numbers, such as in the second half of October, the age-standardized CFR estimate is notably higher when assuming 14 days rather than 7 days (1.27\% vs. $0.79 \%$ on October 29$)$ however still much lower than at the beginning of the pandemic. During the times when the numbers were relatively constant until, say, begin of October 2020 the differences in the CFR estimates with lag 14 or 7 days are smaller. On September 1, the values are $1.25 \%$ and $1.20 \%$ (ratio 1.04), and on October 1, the values are $1.19 \%$ and $1.00 \%$ (ratio 1.19).

\section{Discussion}

In Germany, we observed a reduction of the CFR over time which can only partly be attributed to the changing age distribution of the infected cases towards younger ages. We could also demonstrate that the use of cumulative cases and deaths from the beginning of the pandemic results in a strong overestimation of the CFR, both in Germany and in the other European countries analysed. Since there is no complete ascertainment of Covid-19 cases, our estimates based on the last 60 days may still be an overestimation of the true CFR.

A more complete ascertainment of SARS-CoV-2 infections and Covid-19 cases is only possible under special conditions of closed cohorts or in populations with additional comprehensive sero-surveys. A study on the closed cohort of the Diamond Princess cruise ship in Asia has provided an CFR of $0.99 \%(19,9)$, while a representative population survey in Geneva/Switzerland demonstrated an IFR of $0.64 \%$ (20). The age-standardized CFR in the Diamond Princess population was calculated as $0.65 \%$, which is close to the study from Switzerland and to our calculations from Germany (7). Preliminary results from a nationwide representative sero-survey in Spain showed an overall CFR between $1.1 \%$ and $1.4 \%$ in men and $0.58 \%$ to $0.77 \%$ in women (21). In this study, the CFR increased sharply after age 50, ranging between $11.6 \%$ and $16.4 \%$ in men $\geq 80$ years and between $4.6 \%$ and $6.5 \%$ in women $\geq 80$ years (21). Note that we do not distinguish between infection fatality and case fatality since asymptomatic cases, which occur in various testing settings of COVID-19, are also reported as cases. 
medRxiv preprint doi: https://doi.org/10.1101/2020.11.26.20239327; this version posted November 30, 2020. The copyright holder for this

Although our data support the many studies showing that the CFR attributed to SARS-CoV2/Covid-19 is lower than initially suggested, these results cannot be taken as a message that COVID-19 is just a "light flu" as suggested by some $(22,5)$. An uncontrolled spread of the virus in European countries will certainly result in high numbers of hospitalized patients beyond healthcare capacity and an unacceptable large number of deaths (23).

It is challenging to disentangle the possible causes for the change of the CFR estimates over time. Possible causes for the observed decrease of the CFR are (i) an increase in the detection rate of cases, (ii) improved treatment options, or (iii) mutations of the virus. Testing capacity was limited at the beginning of the pandemic in all countries, and therefore symptomatic cases were more likely to be tested. Before July, about 300.000 to 400.000 tests per week were performed in Germany. In March/April, 6 to $9 \%$ of tests were positive, and this proportion decreased to under $1 \%$ in summer. From July onwards, test numbers increased and reached a plateau of about 1.1 million tests per week by now (24). Afterwards, the proportion of positive tests gradually increased and reached $5 \%$ in by the end of October. It may be appropriate to assume that the proportion of undetected cases is rather constant from, say, August. Furthermore, it is likely that case management has improved with increasing experience in the hospitals, and there is one medication (dexamethasone) which has been shown to significantly reduce the CFR in patients with severe Covid-19 disease (25). Finally, there is currently some but still rather limited evidence for changes in the genetics of the SARS-CoV-2 which may influence outcomes $(14,15,26)$.

Our estimation methods included some assumptions as well as limitations. We aimed to keep the calculations simple using a fixed time from reporting to death. The distribution and its mean may have changed over time towards a shorter interval from infection to reporting. In a period with daily rising numbers, such as in the second half of October, the age-standardized CFR estimate is notably higher when assuming 14 days rather than 7 days. It is possible that a time of 7 days may be too short, which would yield to an underestimation of the CFR when the case numbers are quickly rising. Until mid-October the differences in the CFR estimates with lag 14 or 7 days are small, as shown in the results, and these estimates appear to be robust. 
The time window of 2 months has been chosen arbitrarily. We selected an interval which is long enough to accumulate sufficient numbers for a stable estimation, and short enough to show changes over time clearly. We checked other intervals (one and three months) and found very similar results.

In conclusion, we have suggested an estimate of the CFR of COVID-19 which is based on more recent data only. We recommend not to calculate CRF based on cumulative numbers from the beginning of the pandemic. We showed a decrease of the CFR of COVID-19 over time.

\section{Article Summary}

\section{Strengths and limitations of this study}

- New aspects of estimation of the case fatality risk (CFR) have been investigated

- It has been shown that the CFR decreased over time

- The changing age distribution of the Covid-19 cases only partly explains the decrease

- The CFR in the western European countries are comparable. Remaining differences may be explained by different testing policies and case detection rates

Transparency statement: The corresponding author affirms that this manuscript is an honest, accurate, and transparent account of the study being reported; that no important aspects of the study have been omitted; and that any discrepancies from the study as planned (and, if relevant, registered) have been explained.

\section{Contributorship statement}

Heiko Becher had the study idea, supervised the analysis, wrote the initial draft and most parts of the final version of the manuscript

Katharina Olszewski performed the analysis, and contributed to writing of the manuscript

Sarah Wiegel supervised the analysis and contributed to writing of the manuscript

Olaf Müller contributed to the interpretation of the results and wrote parts of the manuscript 
medRxiv preprint doi: https://doi.org/10.1101/2020.11.26.20239327; this version posted November 30, 2020. The copyright holder for this preprint (which was not certified by peer review) is the author/funder, who has granted medRxiv a license to display the preprint in perpetuity. All rights reserved. No reuse allowed without permission.

All authors approved the final manuscript

\section{Competing Interests}

none

\section{Funding:}

This research has not received additional funding

\section{Data sharing statement}

All data used for this study are from open sources. Data are freely available under

https://npgeo-corona-npgeo-de.hub.arcgis.com/datasets/d4580c810204019a7b8eb3e0b329dd6_0/data.

and

https://www.ecdc.europa.eu/en/publications-data/download-todays-data-geographic-distributioncovid-19-cases-worldwide. 


\section{References}

1. Müller O, Lu G, Jahn A, Razum O. COVID-19 Control: Can Germany Learn From China? Int J Health Policy Manag 2020; 9(10): 432-435. doi: 10.34172/ijhpm.2020.78

2. Müller O, Neuhann F, Razum O. Epidemiologie und Kontrollmaßnahmen bei COVID-19. Dtsch Med Wochenschr 2020; 145(10):670-4.

3. Johns Hopkins University. COVID-19 Dashboard by the Center for Systems Science and Engineering (CSSE) at Johns Hopkins University (JHU); 2020 [cited 2020 Oct 29]. Available from: URL:

https://gisanddata.maps.arcgis.com/apps/opsdashboard/index.html\#/bda7594740fd40299423467b48e9 ecf6.

4. Dong E, Du H, Gardner L. An interactive web-based dashboard to track COVID-19 in real time. The Lancet Infectious Diseases 2020; 20(5):533-4.

5. Ruan S. Likelihood of survival of coronavirus disease 2019. The Lancet Infectious Diseases 2020; 20(6):630-1.

6. Lipsitch M, Donnelly CA, Fraser C, Blake IM, Cori A, Dorigatti I et al. Potential Biases in Estimating Absolute and Relative Case-Fatality Risks during Outbreaks. PLoS Negl Trop Dis 2015; 9(7):e0003846.

7. Vanella P, Wiessner C, Holz A, Krause G, Moehl A, Wiegel S et al. The role of age distribution, time lag between reporting and death and healthcare system capacity on case fatality estimates of COVID-19. MedRxiv [Preprint]. 2020 [cited 2020 Nov 29]. Available from:

https://www.medrxiv.org/content/10.1101/2020.05.16.20104117v1 doi:

https://doi.org/10.1101/2020.05.16.20104117

8. World Health Organisation. Report of the WHO-China Joint Mission on Coronavirus Disease 2019 (COVID-19); 2020 [cited 2020 Nov 2]. Available from: URL:

https://www.who.int/publications/i/item/report-of-the-who-china-joint-mission-on-coronavirusdisease-2019-(covid-19).

9. Mizumoto K, Kagaya K, Zarebski A, Chowell G. Estimating the asymptomatic proportion of coronavirus disease 2019 (COVID-19) cases on board the Diamond Princess cruise ship, Yokohama, Japan, 2020. Euro Surveill 2020; 25(10).

10. Lavezzo E, Franchin E, Ciavarella C, Cuomo-Dannenburg G, Barzon L, Del Vecchio C et al. Suppression of a SARS-CoV-2 outbreak in the Italian municipality of Vo'. Nature 2020; 584(7821):425-9.

11. Fagiuoli S, Lorini FL, Remuzzi G. Adaptations and Lessons in the Province of Bergamo. N Engl J Med 2020; 382(21):e71.

12. Pachetti M, Marini B, Giudici F, Benedetti F, Angeletti S, Ciccozzi M et al. Impact of lockdown on Covid-19 case fatality rate and viral mutations spread in 7 countries in Europe and North America. J Transl Med 2020; 18(1):338.

13. The Lancet Infectious Diseases. Curing COVID-19. The Lancet Infectious Diseases 2020; 20(10):1101. Available from: URL: https://doi.org/10.1016/S1473-3099(20)30706-4.

14. Bhattacharya S, Basu P, Poddar S. Changing epidemiology of SARS-CoV in the context of COVID-19 pandemic. J Prev Med Hyg 2020; 61(2):E130-E136. 
15. Weber S, Ramirez C, Doerfler W. Signal hotspot mutations in SARS-CoV-2 genomes evolve as the virus spreads and actively replicates in different parts of the world. Virus Res 2020; 289:198170.

16. Robert Koch Institut. RKI COVID19; 2020 [cited 2020 Nov 02]. Available from: URL: https://npgeo-corona-npgeode.hub.arcgis.com/datasets/dd4580c810204019a7b8eb3e0b329dd6_0/data.

17. European Centre for Disease Prevention and Control. Download the daily number of new reported cases of COVID-19 by country worldwide; 2020 [cited 2020 Oct 28]. Available from: URL:

https://www.ecdc.europa.eu/en/publications-data/download-todays-data-geographic-distributioncovid-19-cases-worldwide.

18. Gesundheitsberichtserstattung des Bundes. Im Informationssystem der GBE zur Altersstandardisierung benutzte Standardbevölkerungen. Gliederungsmerkmale: Alter, Geschlecht, Standardbevölkerung; 2020 [cited 2020 Oct 28]. Available from: URL: http://www.gbe-bund.de/.

19. Rajgor DD, Lee MH, Archuleta S, Bagdasarian N, Quek SC. The many estimates of the COVID19 case fatality rate. The Lancet Infectious Diseases 2020; 20(7):776-7.

20. Perez-Saez J, Lauer SA, Kaiser L, Regard S, Delaporte E, Guessous I et al. Serology-informed estimates of SARS-CoV-2 infection fatality risk in Geneva, Switzerland. The Lancet Infectious Diseases 2020 [cited 2020 Nov 02]. Available from: URL:

https://www.thelancet.com/journals/laninf/article/PIIS1473-3099(20)30584-3/fulltext doi: https://doi.org/10.1016/S1473-3099(20)30584-3

21. Pastor-Barriuso R, Perez-Gomez B, Hernan MA, Perez-Olmeda M, Yotti R, Oteo J et al. Infection fatality risk for SARS-CoV-2: a nationwide seroepidemiological study in the non-institutionalized population of Spain. medRxiv 20169722 [Preprint]. 2020 [cited 2020 Oct 28]. Available from: URL: https://www.medrxiv.org/content/10.1101/2020.08.06.20169722v2.full.pdf+html doi: https://doi.org/10.1101/2020.08.06.20169722

22. Galvão J. COVID-19: the deadly threat of misinformation. The Lancet Infectious Diseases 2020 [cited 2020 Nov 02]. Available from: URL: https://www.thelancet.com/journals/lanres/article/PIIS1473-3099(20)30721-0/fulltext doi: https://doi.org/10.1016/S1473-3099(20)30721-0

23. Alwan NA, Burgess RA, Ashworth S, Beale R, Bhadelia N, Bogaert D et al. Scientific consensus on the COVID-19 pandemic: we need to act now. The Lancet 2020; 396(10260):e71-e72.

24. Robert Koch Institut. Erfassung der SARS-CoV-2-Testzahlen in Deutschland; 2020 [cited 2020 Oct 28]. Available from: URL: https://www.rki.de/DE/Content/InfAZ/N/Neuartiges_Coronavirus/Testzahl.html.

25. RECOVERY Collaborative Group, Horby P, Lim WS, Emberson JR, Mafham M, Bell JL, Linsell L et al. Dexamethasone in Hospitalized Patients with Covid-19 - Preliminary Report. N Engl J Med 2020 Jul 17:NEJMoa2021436. doi: 10.1056/NEJMoa2021436. PUBMED PMID: 32678530; PMCID: PMC7383595.

26. Young BE, Fong S-W, Chan Y-H, Mak T-M, Ang LW, Anderson DE et al. Effects of a major deletion in the SARS-CoV-2 genome on the severity of infection and the inflammatory response: an observational cohort study. The Lancet 2020; 396(10251):603-11. 
Table 1. CFR estimates according to different estimation methods, Germany and selected European countries, October 29, 2020.

\begin{tabular}{|c|c|c|c|c|c|c|}
\hline Country & Method & Deaths & $\begin{array}{l}\text { Cases, } \\
\text { lag } 7 \\
\text { days }\end{array}$ & $\begin{array}{l}\text { CFR lag } 7 \\
\text { days, \% } \\
95 \% \text { CI }\end{array}$ & $\begin{array}{l}\text { Cases, } \\
\text { lag } 14 \\
\text { days }\end{array}$ & $\begin{array}{l}\text { CFR lag } 14 \\
\text { days, \% } \\
95 \% \text { CI }\end{array}$ \\
\hline \multirow[t]{10}{*}{ Germany } & Crude, total & 10270 & 398654 & $\begin{array}{l}2.58 \\
(2.53-2.63)\end{array}$ & 345468 & $\begin{array}{l}2.97 \\
(2.92-3.03)\end{array}$ \\
\hline & last 2 months & 877 & 164775 & $\begin{array}{l}0.53 \\
(0.50-0.56)\end{array}$ & 121099 & $\begin{array}{l}0.72 \\
(0.69-0.76)\end{array}$ \\
\hline & $\begin{array}{l}\text { Age-standardized }{ }^{\S}, \\
\text { total }\end{array}$ & 10269 & 398034 & $\begin{array}{l}2.47 \\
(2.43-2.52)\end{array}$ & 345060 & $\begin{array}{l}.77 \\
(2.71-2.82)\end{array}$ \\
\hline & last 2 months & 876 & 164255 & $\begin{array}{l}0.79 \\
(0.76-0.83)\end{array}$ & 120784 & $\begin{array}{l}1.27 \\
(1.22-1.31)\end{array}$ \\
\hline & $\begin{array}{l}\text { males, last } 2 \\
\text { months }\end{array}$ & 485 & 84035 & $\begin{array}{l}1.04 \\
(1.00-1.08)\end{array}$ & 62375 & $\begin{array}{l}1.65 \\
(1.60-1.71)\end{array}$ \\
\hline & $\begin{array}{l}\text { females, last } 2 \\
\text { months }\end{array}$ & 389 & 79573 & $\begin{array}{l}0.59 \\
(0.56-0.62)\end{array}$ & 57928 & $\begin{array}{l}0.95 \\
(0.91-0.99)\end{array}$ \\
\hline & $\begin{array}{l}\text { Age } 15-34, \\
\text { last } 2 \text { months }\end{array}$ & 2 & 65033 & $\begin{array}{l}0.0031 \\
(0.0008- \\
0.0053)\end{array}$ & 50328 & $\begin{array}{l}0.0040 \\
(0.0014- \\
0.0065)\end{array}$ \\
\hline & $\begin{array}{l}\text { Age } 35-59, \\
\text { last } 2 \text { months }\end{array}$ & 35 & 59962 & $\begin{array}{l}0.058 \\
(0.049-0.068)\end{array}$ & 42900 & $\begin{array}{l}0.082 \\
(0.070-0.093)\end{array}$ \\
\hline & $\begin{array}{l}\text { Age } 60-79 \\
\quad \text { last } 2 \text { months }\end{array}$ & 250 & 18127 & $\begin{array}{l}1.38 \\
(1.33-1.43)\end{array}$ & 11908 & $\begin{array}{l}2.10 \\
(2.04-2.16)\end{array}$ \\
\hline & $\begin{array}{l}\text { Age } 80+, \\
\quad \text { last } 2 \text { months }\end{array}$ & 589 & 6024 & $\begin{array}{l}9.78 \\
(9.66-9.90)\end{array}$ & 3646 & $\begin{array}{l}16.16 \\
(16.01-16.30)\end{array}$ \\
\hline \multirow[t]{2}{*}{ Belgium } & Crude, total & 11038 & 279323 & $\begin{array}{l}3.95 \\
(3.88-4.02)\end{array}$ & 196544 & $\begin{array}{l}5.62 \\
(5.51-5.72)\end{array}$ \\
\hline & last 2 months & 1154 & 197366 & $\begin{array}{l}0.58 \\
(0.55-0.62) \\
\end{array}$ & 118017 & $\begin{array}{l}0.98 \\
(0.92-1.03)\end{array}$ \\
\hline \multirow[t]{2}{*}{ France } & Crude, total deaths & 35541 & 930745 & $\begin{array}{l}3.82 \\
(3.78-3.86)\end{array}$ & 756472 & $\begin{array}{l}4.70 \\
(4.65-4.75)\end{array}$ \\
\hline & Last 2 months & 4945 & 696345 & $\begin{array}{l}0.71 \\
(0.69-0.73)\end{array}$ & 544261 & $\begin{array}{l}0.91 \\
(0.88-0.93)\end{array}$ \\
\hline \multirow[t]{2}{*}{ Italy } & Crude, total & 37700 & 434449 & $\begin{array}{l}8.68 \\
(8.59-8.76)\end{array}$ & 365467 & $\begin{array}{l}10.32 \\
(10.22-10.42)\end{array}$ \\
\hline & last 2 months & 2228 & 177384 & $\begin{array}{l}1.26 \\
(1.20-1.31)\end{array}$ & 112658 & $\begin{array}{l}1.98 \\
(1.90-2.06)\end{array}$ \\
\hline \multirow[t]{2}{*}{ NL } & Crude, total & 7132 & 244103 & $\begin{array}{l}2.92 \\
(2.85-2.99)\end{array}$ & 188662 & $\begin{array}{l}3.78 \\
(3.69-3.87)\end{array}$ \\
\hline & last 2 months & 921 & 178577 & $\begin{array}{l}0.52 \\
(0.48-0.55) \\
\end{array}$ & 126877 & $\begin{array}{l}0.73 \\
(0.68-0.77) \\
\end{array}$ \\
\hline \multirow[t]{2}{*}{ Romania } & Crude, total deaths & 6574 & 186254 & $\begin{array}{l}3.53 \\
(3.45-3.61)\end{array}$ & 160461 & $\begin{array}{l}4.10 \\
(4.00-4.19)\end{array}$ \\
\hline & last 2 months & 3067 & 109899 & $\begin{array}{l}2.79 \\
(2.69-2.88)\end{array}$ & 92415 & $\begin{array}{l}3.32 \\
(3.20-3.43)\end{array}$ \\
\hline
\end{tabular}


medRxiv preprint doi: https://doi.org/10.1101/2020.11.26.20239327; this version posted November 30, 2020. The copyright holder for this preprint (which was not certified by peer review) is the author/funder, who has granted medRxiv a license to display the preprint in perpetuity. All rights reserved. No reuse allowed without permission.

\begin{tabular}{|c|c|c|c|c|c|c|}
\hline Russia & $\begin{array}{c}\text { Crude, total deaths } \\
\text { last } 2 \text { months }\end{array}$ & $\begin{array}{l}26589 \\
9675\end{array}$ & $\begin{array}{l}1431635 \\
484659\end{array}$ & $\begin{array}{l}1.86 \\
(1.84-1.88) \\
2.00 \\
(1.96-2.04)\end{array}$ & $\begin{array}{l}1326178 \\
413355\end{array}$ & $\begin{array}{l}2.01 \\
(1.96-2.04) \\
2.34 \\
(2.29-2.39)\end{array}$ \\
\hline \multirow[t]{2}{*}{ Spain } & Crude, total & 35298 & 988322 & $\begin{array}{l}3.57 \\
(3.53-3.61)\end{array}$ & 896086 & $\begin{array}{l}3.94 \\
(3.90-3.98)\end{array}$ \\
\hline & last 2 months & 6287 & 602268 & $\begin{array}{l}1.04 \\
(1.02-1.07) \\
\end{array}$ & 553273 & $\begin{array}{l}1.14 \\
(1.11-1.16)\end{array}$ \\
\hline \multirow[t]{2}{*}{ Sweden } & Crude, total & 5918 & 107758 & $\begin{array}{l}5.49 \\
(5.36-5.63)\end{array}$ & 101626 & $\begin{array}{l}5.82 \\
(5.68-5.97)\end{array}$ \\
\hline & last 2 months & 118 & 24944 & $\begin{array}{l}0.47 \\
(0.39-0.56)\end{array}$ & 20571 & $\begin{array}{l}0.57 \\
(0.47-0.68)\end{array}$ \\
\hline \multirow[t]{2}{*}{ Ukraine } & Crude, total deaths & 6590 & 309107 & $\begin{array}{l}2.13 \\
(2.08-2.18)\end{array}$ & 270587 & $\begin{array}{l}2.44 \\
(2.38-2.49)\end{array}$ \\
\hline & last 2 months & 4152 & 208464 & $\begin{array}{l}1.99 \\
(1.93-2.05)\end{array}$ & 182715 & $\begin{array}{l}2.27 \\
(2.20-2.34)\end{array}$ \\
\hline \multirow[t]{2}{*}{ UK } & Crude, total deaths & 45365 & 762542 & $\begin{array}{l}5.95 \\
(5.90-6.00)\end{array}$ & 634920 & $\begin{array}{l}7.14 \\
(7.08-7.21)\end{array}$ \\
\hline & last 2 months & 3879 & 439229 & $\begin{array}{l}0.88 \\
(0.86-0.91)\end{array}$ & 318553 & $\begin{array}{l}1.22 \\
(1.18-1.26)\end{array}$ \\
\hline
\end{tabular}

${ }^{\S}$ some cases with missing age and/or sex 
medRxiv preprint doi: https://doi.org/10.1101/2020.11.26.20239327; this version posted November 30, 2020. The copyright holder for this preprint (which was not certified by peer review) is the author/funder, who has granted medRxiv a license to display the preprint in perpetuity. All rights reserved. No reuse allowed without permission.

Figure 1 CFR estimates, 60-day time window, Germany

Figure 2 Age-adjusted CFR estimates by sex, 60-day time window, Germany

Figure 3 Age-specific CFR estimates, 60-day time window, Germany

Figure 4 Crude CFR estimates, cumulative numbers, selected European countries

Figure 5 Crude CFR estimates, 60-day time window, selected European countries 


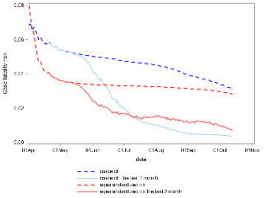




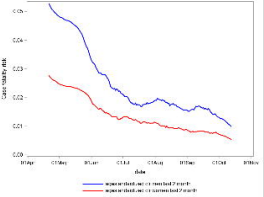




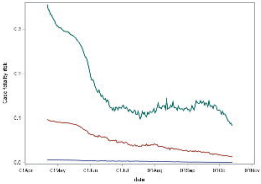




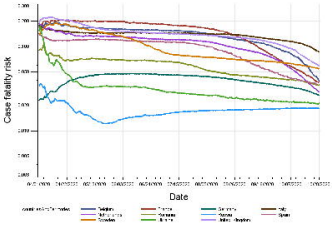




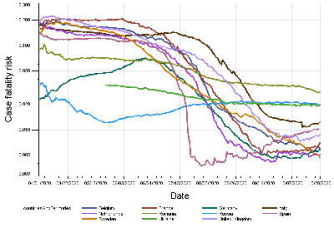

